\title{
EDDY-CURRENT SENSOR FOR A TACHOMETER
}

\section{Jacek PieniążeK, Paulina Ryba}

Katedra Awioniki i Sterowania, Politechnika Rzeszowska (Department of Avionics and Control Systems, Rzeszów University of Technology), al. Powstańców Warszawy 12, 35-959 Rzeszów jp@prz.edu.pl, ryba.ppaulina@gmail.com

\begin{abstract}
The speed of a rotor or rotors of a turbine engine is important information on its operation. Due to the specific conditions, in which the measurement is taken in a turbine engine, which in particular applies to small engines that are becoming increasingly popular in manned and unmanned aviation, the most universal detector is the detector using the phenomenon of eddy currents. This article presents the developed detector system solution. The correct operation of a detector is conditional upon the possibility to detect the presence of a blade in the detection field in a reliable manner, while maintaining the resistance to interference. The developed system is resistant to changes in parameters due to the use of a differential system consisting of two detector coils connected in a bridge circuit, a rectifier circuit with filters acting as a demodulator and a comparator. The system works with a microprocessor performing data processing functions. The executed functional model was tested in a laboratory, which enabled to determine its characteristics in several configurations and to confirm its correct operation. Keywords: rotational speed, eddy currents, measurement system.
\end{abstract}

\section{INTRODUCTION}

The measurement of rotational speed of machines, which contain rotating parts, such as engines and shafts, is important for controlling the motion and monitoring the condition of those machines. In aviation, the rotational speed of a turbine, a shaft of a propulsion engine or a propeller is a primary variable defining the operating condition of a power unit. The speed is also one of the variables used by the pilot and automatic control systems for controlling thrust and identifying the power unit condition.

The measurement of rotational speed in a power unit must take place using technical methods and solutions, which produce correct measurement results over a broad scope of conditions, under which the measurement system components operate. Due to its location in the power unit, the detector is a critical component in terms of reliability as it generates pulses for the metering system that measures speed. The measurement of speed usually takes place by measuring the pulse 
frequency. Thus, although many pulse generation methods are known, such as interrupter, optical, inductive, reluctance, and capacitive methods [1], many of them fail to ensure reliability under conditions of possible soiling or temperature changes, which occur around the power unit engine. From the general principle of cooperation between the detector and the speed measurement system (fig. 1) it follows that it is required that, on the rotating part (1), there should be a component or multiple components (2) which are detected by the detector (3). The detector should shape pulses in a way so that they can be correctly interpreted by the meter (4).

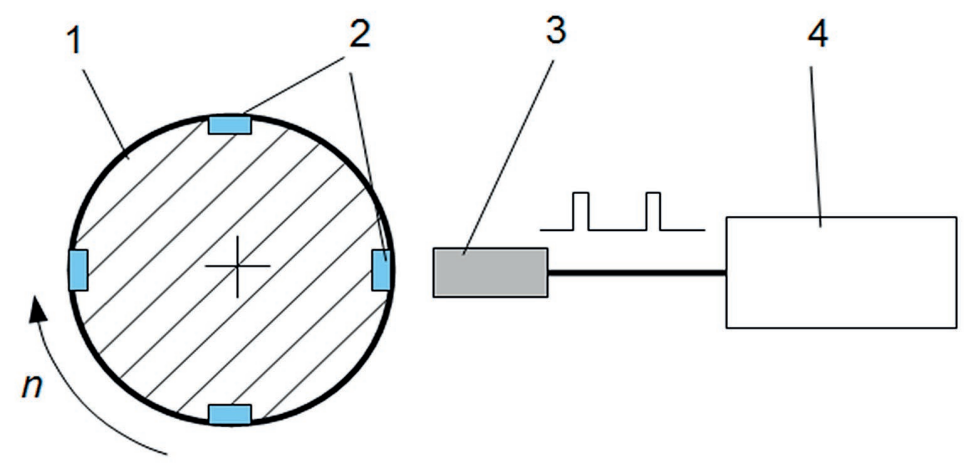

Fig. 1. General operating principle of a speed measuring system [Pieniążek, 2016]

A component detectable by the detector may be an existing machine part (e.g. wheel teeth, turbine or compressor blades), otherwise it will be necessary to add or make a relevant component. Depending on the detector type, that component is:

- a magnet - works with inductive and Hall-effect detectors,

- a reflective component - works with optical reflective detectors,

- a diaphragm-like or translucent component (e.g. an opening) - works with optical detectors,

- a properly shaped component made of a ferromagnetic material - reluctance transmitters.

However, attention should be drawn to the fact that the additional component, especially if it requires introducing a different material, creates technological problems. That is the reason for the widespread application of the reluctance detection method, in which the components generating pulses include: a toothed wheel (a specifically made wheel - e.g. driven from the drive box of the turbine engine accessories or provided by making incisions on the flywheel - in many reciprocating combustion engines) and a detector of magnetic field alterations with a magnet. The magnet with the toothed wheel and, in some transmitters, additional ferromagnetic components shaping the magnetic field, makes a magnetic circuit of variable reluctance. The detector (winding, Hall-effect sensor or a 3-axis magnetoresistor), based on field changes, detects teeth passing through and generates pulses.

The article presents the concept of a speed measurement system for a turbine engine. The measurement system solution (section 4) has been developed based on the analysis of the measurement conditions specific to turbine engines (section 2) and the analysis of characteristics of the systems using eddy currents (section 3). Then, tests were conducted, which were used for fine tuning of the measurement system (section 5) and for specifying its characteristics. 


\section{SPEED MEASUREMENTS IN TURBINE ENGINES}

Turbine engines of different types (mainly turbo-fan, turboprop and turbo-jet ones) are currently the primary drives in passenger aviation. Furthermore, turbine engines are applied more and more widely in power units of small aircraft, are an auxiliary drive of motor gliders or even small unmanned aircrafts [2]. As far as speed measurements in power units of passenger aircrafts have been taken with a high level of reliability, using both inductive and eddy current transmitters, for as long as those engines have existed, the measurements in the power units of unmanned aircrafts are often performed using methods (e.g. optical methods), which should be considered appropriate for experiments, but not for correct operation.

The speed of a turbine power unit depending on the engine type reaches:

- 15,000 (N2), several thousand (N1), depending on the fan size - for large engines,

- 120,000 - in small model engines.

High speed is a considerable difficulty in using the measurement methods, which require a modification of the rotating component (that is e.g. inserting a magnet, making an opening, incising teeth) because of the issue of balancing that rotating component. That is why non-invasive measurement methods using existing components of the power unit have a notable advantage. In a turbine engine, the components, which may be used to obtain a measurement signal, include:

- turbine blades,

- compressor blades,

- gears (reducer in turboprop engines; engine power unit).

The last of the above options is limited to one speed value and applies only to large engines.

It should also be noted that using the turbine involves a major problem being high temperature in the turbine zone.

Using the compressor, i.e. introducing a detector spotting the presence of its blades, is a more practical solution. However, attention should be paid to the fact that the detection method depends on the type of the material, which the compressor is made of. If the material is a soft ferromagnetic one, then it is possible to use the relatively uncomplicated reluctance method.

But the compressor is usually made of materials, which in most cases are paramagnetics (e.g. titanium alloys in compressors of large aircraft engines, light alloys in model engines and engines designed for unmanned aircrafts) [3, 4]. Since electrically that material is a conductor, the effect of inducing eddy currents in the compressor blade may be used for detecting blades.

\section{EDDY-CURRENT DETECTORS AND TRANSMITTERS}

Eddy currents, also known as Foucault currents, are currents flowing and getting closed within the core capacity, and in a uniform material the appearance of their flow trajectory is circular. They emerge as a consequence of a variable magnetic field inducing a flow of charges in a conducting material. The induced currents have a varied spatial intensity depending on depth and distance from the inducing coil axis.

Those currents generate a secondary magnetic field by changing voltage in the sensor coil, and as a consequence, induction coil reluctance decreases. 
Sensors may be used under conditions of the tested material being soiled, because magnetic field is unaffected by typical solid (dust) or liquid (water, oil) contamination. Eddy-current sensors and transmitters consist of one or multiple coils, which induce eddy currents in a material and detect currents by changing inductance. The winding method, the shaping of the core or its absence, and the number of turns in the coil influence the detector characteristics. The dependence consisting in the depth of penetration for a given material decreasing with the increase in the power supply frequency is also known $[5,6]$. That is why when using eddy currents to detect the presence of a compressor blade, while increasing the power supply frequency, one may expect a decrease in the level of signal caused by generating eddy currents.

The aforesaid effects enable to use eddy currents for measuring of thicknesses of non-conducting layers (e.g. varnish) on a conductor surface. An important application is using eddy current methods to detect structural damages or changes to the internal structure of materials [7]. A change in the signal from an eddy-current transmitter enables to determine the positions of conducting components. In diagnostic systems of rotating components, such as compressors and turbines, the effect of size changes (e.g. as a result of damage) and emerging vibrations on the characteristics of an eddy-current detector response [8, 9, 10] can be applied. In most applications of that type, a pulse system is used, in which eddy currents are induced as a result of components passing close to a permanent magnet, whereas a coil is a detecting component, from which the signal should be subjected to analysis $[9,10]$. The eddy current methods are also used for measuring of rooms, e.g. pressure transmitter membrane deformation [11]. Two windings are often used in transmitters, which enables to take differential measurements, and at the same time, compensates for component parameter changes. Systems with eddy-current transmitters get miniaturized due to a lithographic design of the windings and integrating the transmitter with detector systems [12].

The detection for speed measurement does not require compressor blade position measurement, but reliable pulse generation. The correctness of blade detection is conditional upon the level of the obtained signal. Changes to inductance causing voltage fluctuations in the detection system are conditional upon both the type of the material blades are made of and blade geometry, which influences the shape of current lines, and upon the distance between the detector and the blade. A low signal level makes it necessary to use a high-sensitivity detection system which, however, must be resistant to noise present in the system.

\section{SPEED MEASUREMENT SYSTEM USING THE PULSE METHOD}

\subsection{Overall structure of the measurement system}

The detector system detecting the blades moving close to energized detector windings generates a voltage signal, which is formed using an analog circuit and a comparator. The tachometer measurement system with an eddy-current transmitter consists of the following components:

- eddy-current detector coils,

- AC adapter,

- detection system,

- pulse counting system. 


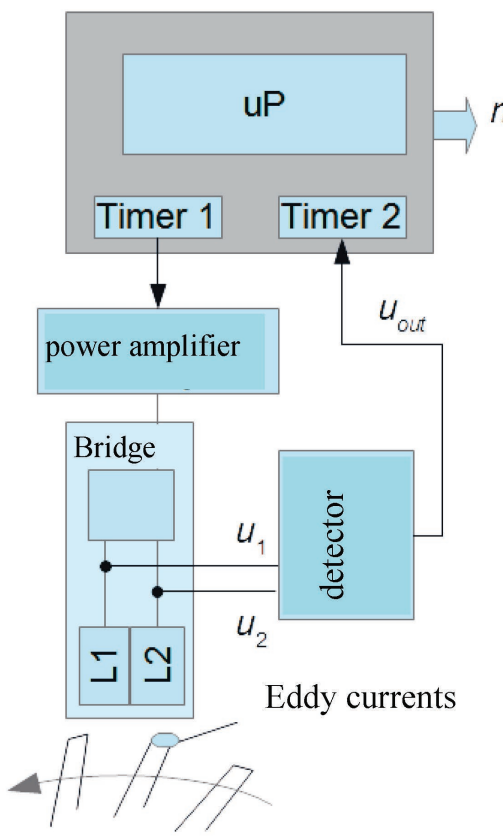

Fig. 2. The structure of the measurement system with an eddy-current detector [Pieniążek, Ryba, 2016]

The components listed in the target system (fig. 2) are made using the microprocessor technology. Executing an adapter using a counter circuit (Timer 1) and a power amplifier is possible, which has been proven by tests with the system supply using a square wave (section 5). The other counter circuit is used for measurement of the frequency generated by blades moving close to the detector. The microprocessor converts the frequency to speed.

\subsection{Eddy-current detector}

In an eddy-current detector adapted to and designed for working with turbine blades, the magnetic field generated by the inductive component should be appropriately shaped. The field should be pointed toward the blade, which has been accomplished by introducing a core. Detection based on the measurement of changes to the field generated by the presence or absence of a blade (fig. 3a) in the detection area with a single winding may work incorrectly due to environmental impacts on the detector components (winding resistance, core permeability, of which changes may impact the output signal just as eddy currents do) and on other electronic components. Using a differential detector configuration (fig. 3b) results in self-compensation for parameter changes of the detector components. The factors, which result in changing parameters of the detector components ( $\mu_{\mathrm{R}}$ and consequently $L$; winding resistance $R$ ) in the differential system, have the same influence on both windings. 


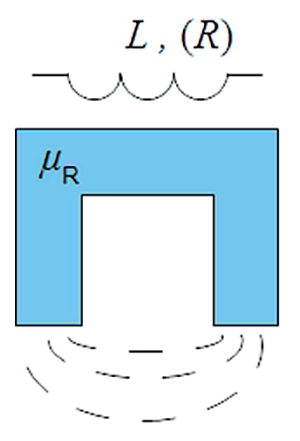

a)

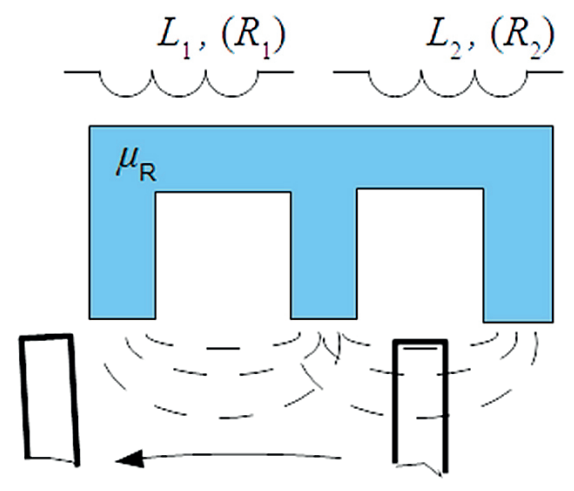

b)

Fig. 3. Eddy-current detector, a - absolute, b - differential [Pieniążek, Ryba, 2016]

The next issue to be solved is the selection of the detector power supply frequencies. The effect of a change to the depth, to which eddy currents are induced, described in section 3, suggests that using lower frequencies should increase detection sensitivity. However, with regard to the maximum speed and the number of compressor blades, the pulse frequency may reach:

- $12 \mathrm{kHz}$ - for a high-pressure compressor of a large turbine engine and less for other components, - $40 \mathrm{kHz}$ - in a small model engine.

The inducing frequency should be significantly (i.e. over 10 times) higher than the pulse frequency. But it is not possible to freely increase that frequency as another limitation is the characteristics of the core shaping the magnetic circuit with respect to high frequencies. Hence the necessity to select a core material, which will work properly at the assumed power supply frequency. The prepared model uses a core of material $3 \mathrm{~F} 3$, which is used in high-frequency circuits.

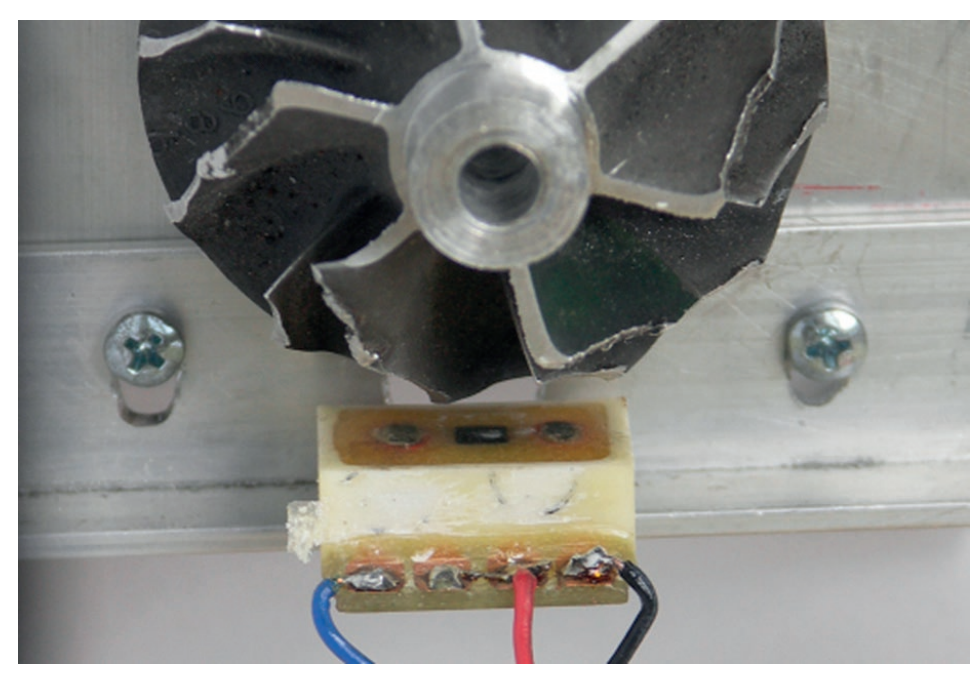

Fig. 4. View of the detector in the test station [Pieniążek, 2016] 
In the prepared functional model, the power supply frequency of $1 \mathrm{MHz}$ was used, which should ensure obtaining a correct signal for small jet engines that place the highest requirements on the detector. The core dimensions (distance between extreme pole pieces $-12 \mathrm{~mm}$, thickness $-4 \mathrm{~mm}$ ) have been defined for a small compressor (fig. 4) as the target application for the designed system is the measurement of the rotational speed of a model engine. In systems ultimately designed for specific engines, the core dimensions should be matched to the compressor geometry. Fig. 4 shows a detector placed in an enclosure suited to be put in a test station. The adopted fixing method enables to adjust the detector's distance from the blades.

\subsection{Eddy-current detector electronic system}

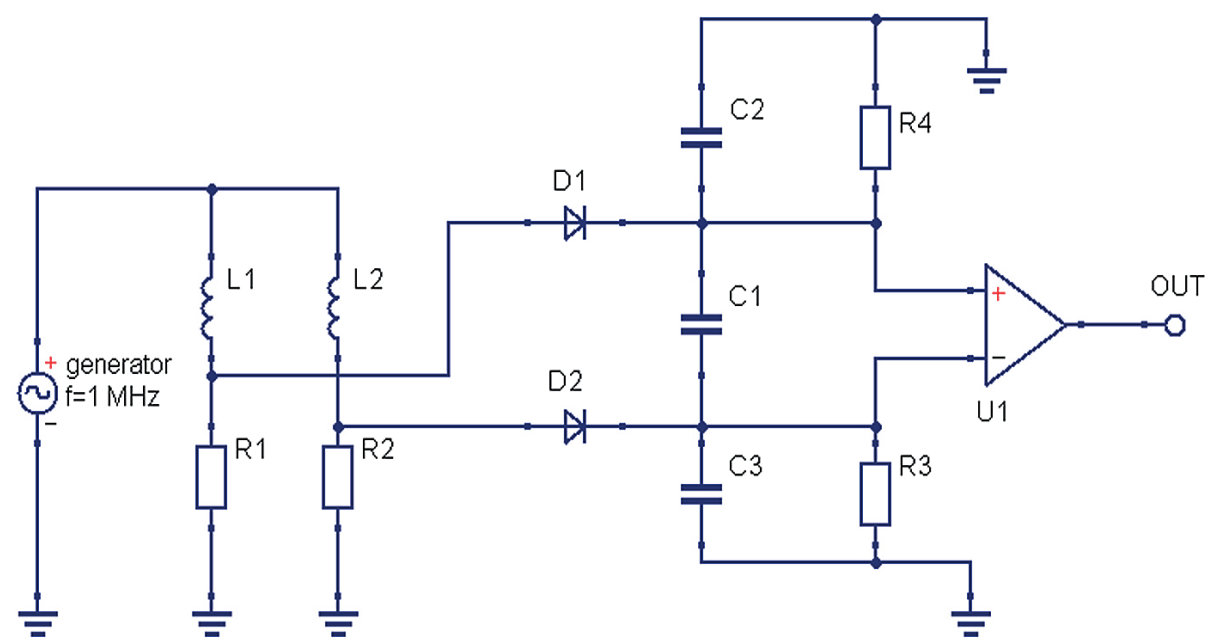

Fig. 5. The detector version with symmetrical power supply [Pieniążek, Ryba, 2016]

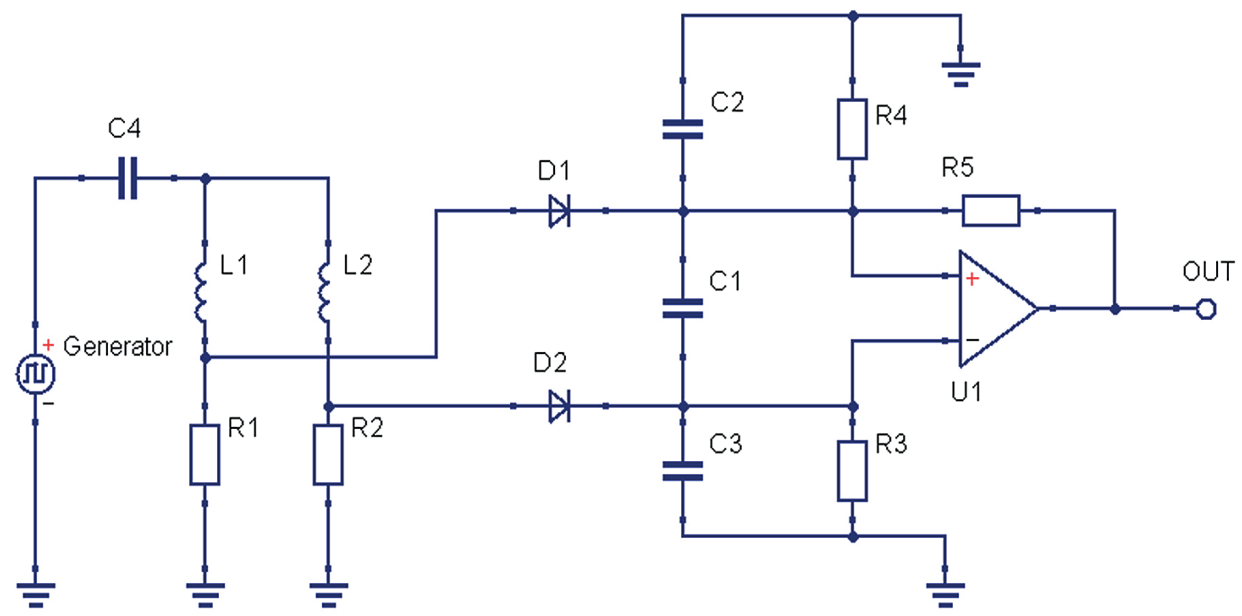

Fig. 6. The detector version with unipolar square power supply and increased comparator hysteresis [Pieniążek, 2016] 
The detector windings working in a differential system are connected in a bridge circuit - windings L1 and L2 as well as resistances R1 and R2 (fig. 5 and 6). The detector system consists of diodes D1 and D2, which make a half-wave rectifier, capacitors C1, C2 and C3, which together with resistors R3 and R4 make high-pass filters shaping the input signal of comparator U1. Due to the symmetry of the filter circuits, changes to the parameters of the electronic components caused by temperature changes should get compensated. The comparator is a component, which may demonstrate sensitivity to temperature changes. Thus, when determining the minimum sensitivity level, it is necessary to consider the imbalance voltage of the applied comparator and the temperature coefficient of that voltage.

The bridge circuit has been made in two versions, which differ in power supply methods. In the circuit shown in fig. 6 , capacitor $\mathrm{C} 4$ is introduced in series with the bridge.

The two detector versions shown in fig. 5 and 6 additionally differ from each other by introducing resistor R5, which by increasing the hysteresis improves the detector's resistance to interference.

\section{TESTING THE EDDY-CURRENT DETECTOR SYSTEM}

The detector concept was tested in a laboratory. The windings shown in fig. 4 were used. A functional generator was used for supplying the bridge circuit to determine how the detector behaves with different types of power supply. The system was tuned to work with $1 \mathrm{MHz}$ power supply. During the test, the blade distance from the detector was $0.3 \mathrm{~mm}$. The maximum distance of correct detector operation for the applied rotor and signal processing circuit is approx. $0.7 \mathrm{~mm}$. The maximum distance for correct detector operation obviously depends on the material of the compressor blades and their shape; those factors determine the resultant inductance change caused by the presence of a blade in the detection area.

In the first test, power supply with a sinusoidal waveform of an amplitude of approx. $10 \mathrm{~V}$ was applied. Fig. 7 shows the following voltages:

$\mathrm{U}_{\mathrm{z}}$ - supply voltage,

$\mathrm{U} 1, \mathrm{U} 2$ - at comparator inputs (as shown in fig. 5),

$\Delta \mathrm{U}$ - difference between voltages at the comparator input,

$\mathrm{U}_{\mathrm{wy}}$ - comparator output voltage.

$\mathrm{U} 1$ and $\mathrm{U} 2$ voltage values change depending on the compressor blade positions (compare fig. $7 \mathrm{a}$ and $7 \mathrm{~b}$ ). The resulting changes are approx. $10 \mathrm{mV}$ for values of those voltages of approx. $650 \mathrm{mVpp}$. It is noticeable that voltage $\Delta \mathrm{U}$ includes a variable component of the power supply frequency and noise at $15 \mathrm{mVpp}$ (demodulation interference). The occurrence of a relatively strong interference justifies introducing the comparator hysteresis.

Further experiments were conducted using the square wave power supply. Fig. 8 shows voltage waveform (as described above) when the detector was supplied with the voltage having an amplitude of approx. $5 \mathrm{~V}$; the visible distortion of the waveform results from the generator load introduced by the detector system. The changes to U1 and U2 voltages are at several $\mathrm{mV}$ with changes to those voltages at any time of power supply being $400 \mathrm{mVpp}$. The system behaves similarly as in the previous experiment, however, high-frequency interferences are visible, which are induced at times of changing the supply voltage value. 


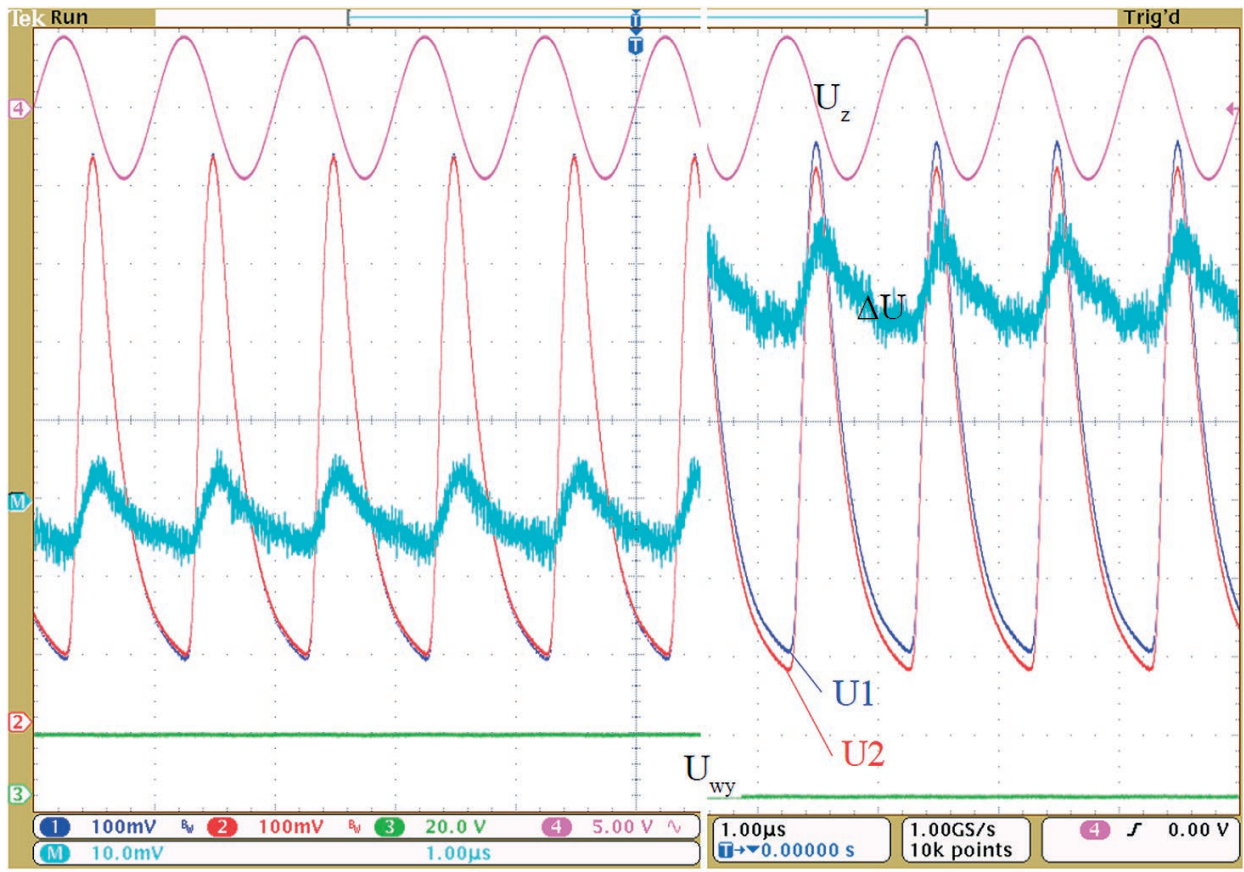

Fig. 7. Voltages in the eddy-current detector system supplied with the sinusoidal voltage: a), b) - for different blade positions (scaling of individual voltages according to the description of individual channels in the lower line) [Pieniążek, 2016]

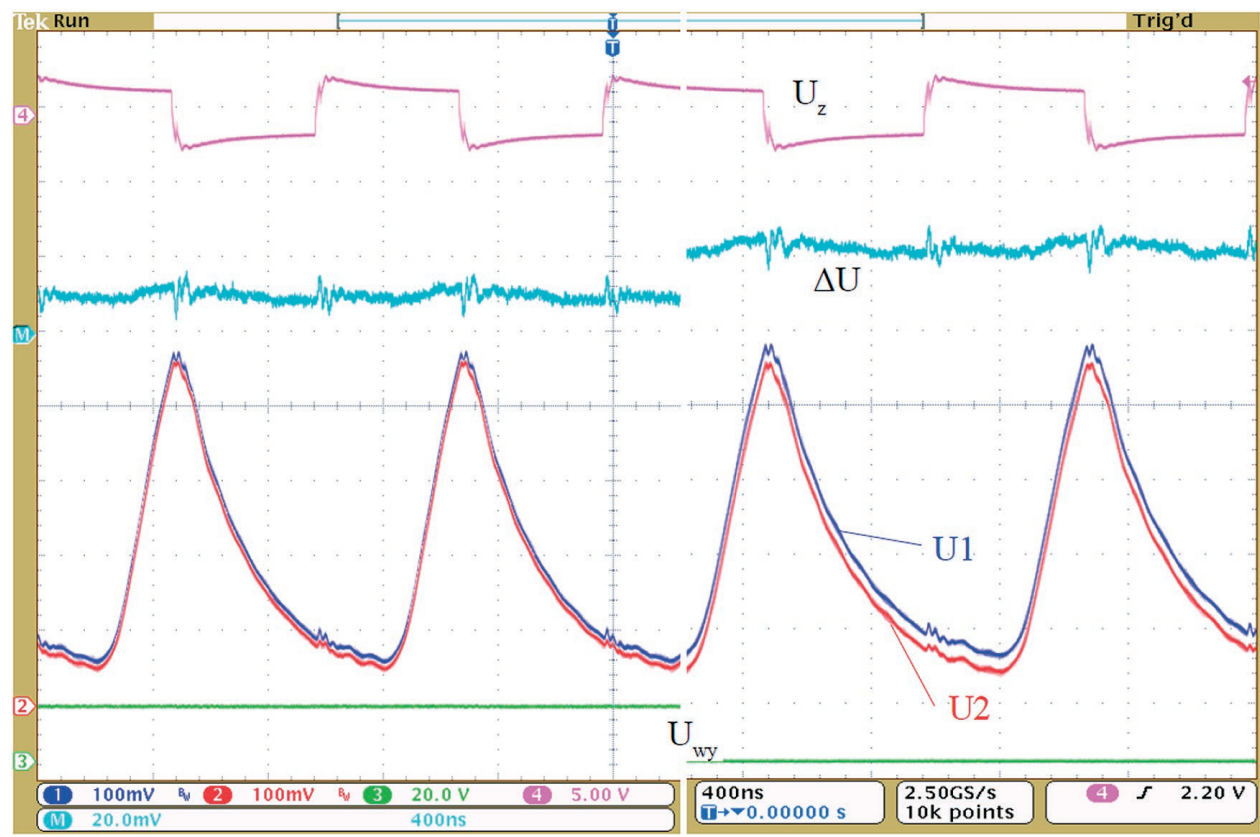

Fig. 8. Voltages in the eddy-current detector system supplied with the square voltage, version as in fig. 5: a), b) - for different blade positions [Pieniążek, 2016] 


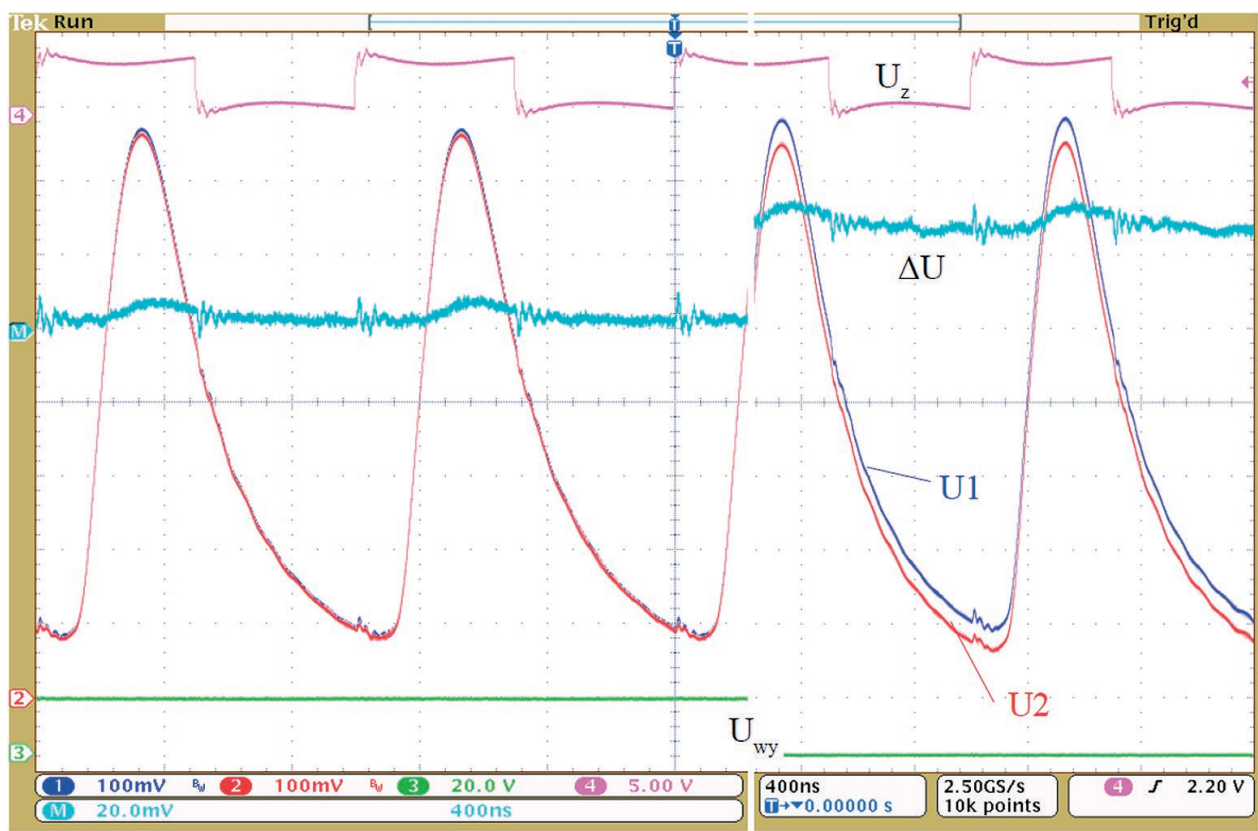

Fig. 9. Voltages in the eddy-current detector system supplied with the square voltage, version as in fig. 6 : $\mathrm{a}, \mathrm{b}$ - for different blade positions [Pieniążek, 2016]

Introducing power supply through a capacitor, selected for the frequency of $1 \mathrm{MHz}$, resulted in an increase in voltage levels (fig. 9). In particular, increase of the U1 and U2 voltage levels from $400 \mathrm{mVpp}$ to $700 \mathrm{mVpp}$ (fig. 10) has two effects:

1. increasing the level of voltage difference at the comparator input,

2. shifting the maximum $\Delta \mathrm{U}$ moment by the instant when the supply voltage changes and the high-frequency interferences occur.

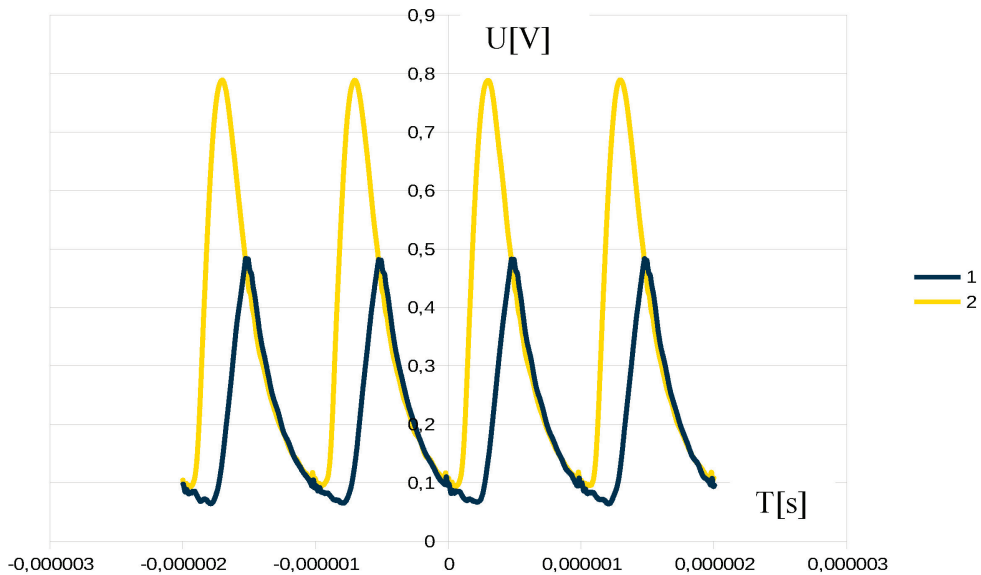

Fig. 10. Voltage at one of the comparator inputs. 1 - direct power supply, 2 - power supply through the capacitor [Pieniążek, 2016] 
The level of changes to the $\Delta U$ voltage value depending on the blade position is similar to that for power supply with a sinusoidal signal. It should be noted that it is achievable at twice lower supply voltage levels. Reducing the demodulation interference level is also a noticeable effect

When using the system configured as in fig. 6, its operation does not depend on the supply voltage constant component. In the experiment, of which results are shown in fig. 9, the unipolar square wave power supply with voltage values of 0 and $10 \mathrm{~V}$ was used (distortions of actual voltage measured at the input result from the load nature). That power supply method is easily obtainable in a microprocessor circuit by controlling the transistor keys.

When comparing the individual results, it is noticeable that the application of the system from fig. 6 and the unipolar two-state power supply offers better effects than using the more complex (requiring an extra generator system) sinusoidal power supply.

A certain inconvenience of the power supply with switchable voltage compared to the power supply with sinusoidal voltage is the possibility of inducing the higher-frequency interferences caused by step functions. The level of those interferences is lower than the detector primary operating frequency and their reduction should be possible by way of shielding the system and signal lines.

\section{SUMMARY}

The article presented the concept of a speed measurement system, of which design accounts for the operating conditions in a turbine engine. The system uses a differential eddy-current detector, which proved the best suited to the operating conditions. The most important part of operation refers to the electronic system generating a signal for the counter circuit. The system was designed considering the characteristics of its measurement task, and then tested in several configurations. As part of the tests, the system characteristics were defined depending on the shape of the supply voltage and system version. Due to the application of the system adjusted to work with an assumed frequency, the detector may be supplied with switchable (square) voltage, which greatly facilitates practical operation compared to the use of a supply generator having a defined signal shape. The demonstrated results confirm its feasibility and offer guidelines as to how the measurement system should be made.

\section{LITERATURE}

[1] Jakubiec, W., Zator, S. i Majda, P., 2014, Metrologia (Metrology), Polskie Wydawnictwo Ekonomiczne, Warszawa.

[2] Aircraft Engines, První Brněnská Strojírna Velká Bíteš, http://www.pbsvb.com/customerindustries/aerospace/aircraft-engines

[3] Ronald D. Flack, 2005, Fundamentals of Jet Propulsion with Applications, Cambridge University Press.

[4] Saravanamutto, H. I. H., Rogers G. F. C., Cohen H, Straznicky P. V., 2009, Gas Turbine Theory. $6^{\text {th }}$ Edition, Pearson Education Limited. 
[5] Wrzuszczak, M., 2011, Modelowanie przetworników wiroprądowych. Wybrane zagadnienia (Modelling of the Eddy current sensors. Selected topics), Politechnika Opolska, Opole.

[6] Rawa, H., 2001, Elektryczność i magnetyzm w technice (Electricity and megnetism in technology), PWN, Warszawa.

[7] Blodgett, M. \& Peter B. Nagy, 1999, Eddy Current Elevation of Electrical Anisotropy in Polycrystalline Ti-6AL-4V, Plenum Publisher.

[8] Yuqing, Lai, 2005, Eddy Current Displacement Sensor with LTCC Technology, PhD Thesis, Universität Freiburg, Switzerland.

[9] Flotow, A. and Drumm, M. J., 2006, Blade-tip monitoring with through-the-case eddy current sensors, Sensors online, No. 6.

[10] Mandache, C., Mcelhinny, T. and Mrad, N., 2012, “Aircraft Engine Blade Tip Monitoring Using Pulsed Eddy Current Technology", 4th International Symposium on NDT in Aerospace.

[11] Nabavi, M. R., Nihtianov, S., 2011, "Eddy-Current Sensor Interface for Advanced Industrial Applications", IEEE Transactions on Industrial Electronics, VOL. 58, NO. 9.

[12] Sadler, D. J., Ahn, C. H., 2001, “On-chip eddy current sensor for proximity sensing and crack detection", Sensors and Actuators, A 91, pp. 340-345.

[13] Ryba, P., 2015, Czujnik wiroprądowy do obrotomierza (Eddy Current Sensor to the Tachometer), Praca dyplomowa, WBMiL, Politechnika Rzeszowska, Rzeszów.

\section{CZUJNIK WIROPRĄDOWY DO OBROTOMIERZA}

\section{Streszczenie}

Prędkość obrotowa wirnika lub wirników silnika turbinowego stanowią istotną informację o stanie pracy tegoż. Ze względu na specyfikę warunków w jakich wykonuje się pomiar w silniku turbinowym, a w szczególności dotyczy to małych silników, które zdobywają coraz większą popularność w lotnictwie załogowym i bezzałogowym, najbardziej uniwersalnym detektorem jest detektor wykorzystujący zjawisko prądów wirowych. W artykule zaprezentowane zostało rozwiązanie opracowanego układu detektora. Poprawna praca detektora jest uwarunkowana możliwością pewnego wykrycia obecności łopatki w polu detekcji przy odporności na zakłócenia. Opracowany układ jest odporny na zmiany parametrów dzięki zastosowaniu układu różnicowego składającego się z dwu cewek detektora połączonych w układzie mostkowym, układu prostownika z filtrami pełniących funkcję demodulatora oraz komparatora. Układ ten współpracuje z mikroprocesorem realizującym funkcje przetwarzania danych. Wykonany model funkcjonalny został przebadany w laboratorium co pozwoliło określić jego właściwości w kilku konfiguracjach i potwierdzić poprawność działania.

Słowa kluczowe: prędkość obrotowa, prądy wirowe, układ pomiarowy. 